\title{
Stability of High-Level Waste Forms
}

June 13, 2003

Lead Principal Investigator: Theodore M. Besmann

Oak Ridge National Laboratory

P.O. Box 2008

Oak Ridge, TN 37831-6063

Phone: (865) 574-6852

Co-Investigator:

E-mail: besmanntm@ornl.gov

John D. Vienna

Pacific Northwest National Laboratory

P. O. box 999

Richland, WA 99352

Phone: (509) 372-2807

E-mail: john.vienna@pnl.gov

Contributors: $\quad$ Nagraj Kulkarni, Oak Ridge National Laboratory

Karl E. Spear, Pennsylvania State University

RESEARCH OBJECTIVE: The objective of the proposed effort is to use a new approach to develop solution models of complex waste glass systems and spent fuel that are predictive with regard to composition, phase separation, and volatility. The effort will also yield thermodynamic values for waste components that are fundamentally required for corrosion models used to predict the leaching/corrosion behavior for waste glass and spent fuel material. This basic information and understanding of chemical behavior can subsequently be used directly in computational models of leaching and transport in geologic media, in designing and engineering waste forms and barrier systems, and in prediction of chemical interactions.

RESEARCH PROGRESS AND IMPLICATIONS: As of the end of the second year of this project, which is a continuation of a previous three-year EMSP effort, the 14-element ChemSage datafile containing: Na-K-Ca-Mg-Fe-Al-B-Si-O-H-S-C-N-Sn has been upgraded as new binary and ternary assessments are completed. This file has been converted into FactSage databases (one for compounds, and one for each solution phase). The FactSage program is particularly useful for calculating and displaying isothermal ternary sections that can be compared with reported literature data.

The use of the modified associate species model for the glass solution phase easily allows for the addition of new and/or revised data assessments. Thus, the building of the 14-element database has largely consisted of adding the binary and ternary assessment results to the existing database without the need for extensive revision of the entire database.

Several systems were thoroughly assessed during the past year. The $\mathrm{CaO}-\mathrm{MgO}$ system was 
reassessed, and a solid solution phase and new associate species added to the database so that the data accurately reproduce the accepted liquidus and solid solution values. The ternary $\mathrm{Na}_{2} \mathrm{O}-\mathrm{CaO}-\mathrm{SiO}_{2}$ system required extensive work since the phase diagram is quite sensitive to the relative stabilities of the compound phases. A fine-tuned reassessment of the $\mathrm{CaO}-\mathrm{SiO}_{2}$ binary system was required in order to develop accurate ternary information. The new $\mathrm{CaO}-\mathrm{SiO}_{2}$ information was then used in starting a reassessment of the $\mathrm{CaO}-\mathrm{Al}_{2} \mathrm{O}_{3}-\mathrm{SiO}_{2}$ system. The solidus diagram is now completed, and the liquidus surface is being examined. Minor components of sulfate and water in a glass result from combustion melting and fining of the melt. Our database now includes associate species that will allow for the calculation of concentrations of these components in the glass as a function of temperature, glass composition, and gas environment.

The data for the $\mathrm{Na}_{2} \mathrm{O}-\mathrm{Al}_{2} \mathrm{O}_{3}-\mathrm{B}_{2} \mathrm{O}_{3}-\mathrm{SiO}_{2}$ system was evaluated again, particularly along the $\mathrm{NaAlO}_{2}-$ $\mathrm{NaAlSiO}_{4}-\mathrm{SiO}_{2}$ pseudo-binary since new experimental data are available on the nepheline liquidus temperature when $\mathrm{B}_{2} \mathrm{O}_{3}$ is added to nepheline compositions. Differences between experimental and calculated results are still being examined. Precipitation of albite from the glass melt rather than nepheline would explain the differences, but all possibilities are being considered. Reassessments of binary $\mathrm{Al}_{2} \mathrm{O}_{3}-\mathrm{B}_{2} \mathrm{O}_{3}, \mathrm{SiO}_{2}-\mathrm{B}_{2} \mathrm{O}_{3}, \mathrm{Na}_{2} \mathrm{O}-\mathrm{B}_{2} \mathrm{O}_{3}$ systems were performed, but so far have led to little changes in the calculated $\mathrm{B}_{2} \mathrm{O}_{3}$ fluxing temperatures.

Spinel forming phases have been the focus of parallel efforts. Sub-models of the $\mathrm{Na}_{2} \mathrm{O}-\mathrm{Al}_{2} \mathrm{O}_{3}-\mathrm{B}_{2} \mathrm{O}_{3}$ $\mathrm{SiO}_{2}$ system together with $\mathrm{Cr}_{2} \mathrm{O}_{3}, \mathrm{MnO}$, and $\mathrm{NiO}$ have been successfully developed. These have been integrated into database for use in ChemSage and FACTSage for the system $\mathrm{Na}_{2} \mathrm{O}-\mathrm{Al}_{2} \mathrm{O}_{3}-\mathrm{Cr}_{2} \mathrm{O}_{3}$ $\mathrm{MnO}-\mathrm{NiO}-\mathrm{B}_{2} \mathrm{O}_{3}-\mathrm{SiO}_{2}$. Currently, a model for the crystalline spinel phase that includes $\mathrm{Cr}_{2} \mathrm{O}_{3}, \mathrm{MnO}$, and $\mathrm{NiO}$ together has yet to be included. An existing model in the FACTSage system is being used temporarily. Efforts on modeling the $\mathrm{Na}_{2} \mathrm{O}-\mathrm{Al}_{2} \mathrm{O}_{3}-\mathrm{B}_{2} \mathrm{O}_{3}-\mathrm{SiO}_{2}$ system with $\mathrm{ZrO}_{2}$ have been successful and that sub-model is complete.

A set of liquidus temperature and heat capacity data for the five oxide component system: $\mathrm{Na}_{2} \mathrm{O}-\mathrm{CaO}$ $\mathrm{Al}_{2} \mathrm{O}_{3}-\mathrm{B}_{2} \mathrm{O} 3-\mathrm{SiO}_{2}$ was experimentally developed and tested. Test data on the solubility of $\mathrm{Cr}_{2} \mathrm{O}_{3}$ in the melt and liquidus temperature of glasses in the $\mathrm{MnO}, \mathrm{Cr}_{2} \mathrm{O}_{3}, \mathrm{NiO}, \mathrm{Fe}_{2} \mathrm{O}_{3}$ spinel primary

phase field were systematically measured. This data was used in the development of several submodels including:

- Binary systems of $\mathrm{Na}_{2} \mathrm{O}, \mathrm{Al}_{2} \mathrm{O}_{3}, \mathrm{~B}_{2} \mathrm{O}_{3}, \mathrm{SiO}_{2}, \mathrm{CaO}$ plus partial binaries with $\mathrm{NiO}, \mathrm{Cr}_{2} \mathrm{O}_{3}, \mathrm{Li}_{2} \mathrm{O}, \mathrm{K}_{2} \mathrm{O}, \mathrm{MgO}, \mathrm{FeO}$, and $\mathrm{Fe}_{2} \mathrm{O}_{3}$.

- Ternary systems of $\mathrm{Na}_{2} \mathrm{O}, \mathrm{B}_{2} \mathrm{O}_{3}, \mathrm{Al}_{2} \mathrm{O}_{3}, \mathrm{SiO}_{2}$, and $\mathrm{CaO}$ plus partial ternaries with $\mathrm{NiO}, \mathrm{FeO}$, and $\mathrm{Li}_{2} \mathrm{O}$

- Plus a growing multi-component system of $\mathrm{Na}_{2} \mathrm{O}-\mathrm{Al}_{2} \mathrm{O}_{3}-\mathrm{Cr}_{2} \mathrm{O}_{3}-\mathrm{NiO}-\mathrm{B}_{2} \mathrm{O} 3-\mathrm{SiO}_{2}$ and $\mathrm{Al}_{2} \mathrm{O}_{3}-\mathrm{B}_{2} \mathrm{O}_{3}-\mathrm{CaO}-\mathrm{Na}_{2} \mathrm{O}-\mathrm{SiO}_{2}$

PLANNED ACTIVITIES: In the coming period we will be engaged in further refining and expanding the model for high-level nuclear waste glass. $\mathrm{CaO}$ and $\mathrm{ZrO}_{2}$ will be accurately integrated into the model. A new formalism for spinel will be developed and included in the global model. Important nonmetals will also be included, such as sulfur and phosphorus. In the final stages of the effort we will 
include critical radionuclides such as the actinides.

Experimental activities will include critical experiments with regard to $\mathrm{CaO}$ activity measurements. Spinel formation will be assessed as this complex and not well-defined problem will need experimental data to check and refine the model. The models for the non-metals such as sulfur and phosphorus will also need to be validated with experimental determinations of chemical activity.

\section{INFORMATION ACCESS:}

\section{PUBLICATIONS}

T. M. Besmann and K. E. Spear, "Thermochemical Modeling of Oxide Glasses," J. Am. Ceram. Soc. 85, 2887 (2002).

T. M. Besmann, K. E. Spear, and J. D. Vienna, "Extension Of The Modified Associate Species Thermochemical Model For High-Level Nuclear Waste Glass," Proc. Fall Meeting of the MRS, 2002, in press.

T. M. Besmann, N. S. Kulkarni, and K. E. Spear, "Thermochemical And Phase Equilibria Property Prediction For Oxide Glass Systems Based On The Modified Associate Species Approach,” Proc., $103^{\text {rd }}$ Meeting of the Electrochemical Society, 2003, in press.

N. Kulkarni, T. M. Besmann, and K. E. Spear, "Thermodynamic Database for Waste Oxide Glasses," Proc. Annual Meeting of the American Ceramic Society, 2003, in preparation.

\section{PRESENTATIONS}

Karl E. Spear, "High Level Nuclear Waste Glass: Thermochemical Modeling of Stabilities," San Francisco Section of the Electrochemical Society, Palo Alto, CA, Dec. 9, 2003

Karl Spear, Theodore Besmann, and Nagraj Kulkarni, "Application of a Modified Associate Species Model to Chemically Complex Oxide Glass Solutions," Calphad XXXII, La Malbaie, Quebec, Canada, May 29, 2003.

T. M. Besmann, K. E. Spear, and J. D. Vienna, "Extension Of The Modified Associate Species Thermochemical Model For High-Level Nuclear Waste Glass," Fall Meeting of the MRS, Dec. 1-6, 2002.

N. Kulkarni, T. M. Besmann, and K. E. Spear, "Thermodynamic Database for Waste Oxide Glasses," Annual Meeting of the American Ceramic Society, April 27-30, 2003.

T. M. Besmann, "Modified Associate Species Thermochemical Model For Oxide Systems," Seminar, Research Center Juelich, Germany, May 5, 2003. 
T. M. Besmann, N. S. Kulkarni, and K. E. Spear, "Thermochemical And Phase Equilibria Property Prediction For Oxide Glass Systems Based On The Modified Associate Species Approach," $103^{\text {rd }}$ Meeting of the Electrochemical Society, April 27- May 2, 2003. 